\title{
PULAU BURU MASA PERANG DUNIA II: Perspektif Arkeo-Historis
}

\section{Buru Island during World War II: Historical-Archaeology Perspective}

\author{
Syahruddin Mansyur \\ Balai Arkeologi Ambon \\ Jl. Namalatu-Latuhalat, Nusaniwe, Ambon-97118 \\ e-mail: hitam_putih07@yahoo.com
}

\begin{abstract}
Abstrak
Dalam konteks kawasan, keberadaan tinggalan arkeologi berupa sarana pertahanan masa Perang Dunia II di Pulau Buru tidak lepas dari konteks geografis, dimana Kepulauan Maluku - termasuk Pulau Buru merupakan bagian dari kawasan Pasifik. Permasalahan yang dikaji dalam tulisan ini adalah mengungkap berbagai bentuk sarana pertahanan dan lokasi keberadaannmya, serta informasi historis yang terkait dengan Perang Dunia II di Pulau Buru. Dengan menggunakan metode analisis deskriptif dan analogi sejarah, penelitian ini berhasil mengidentifikasi bentuk-bentuk sarana pertahanan yang masih dapat diamati berupa; fasilitas landasan pacu, pillbox dan lokasi pendaratan pasukan Australia. Hasil pembahasan juga berhasil mengungkap peran wilayah Pulau Buru yang merupakan wilayah strategis baik bagi militer Jepang maupun pasukan sekutu dalam Perang Dunia II. Peran wilayah yang strategis ini tidak lepas dari posisi geografis Pulau Buru yang dapat menghubungkan Philipina yang ada di bagian utara, Ambon yang ada di sebelah timur, serta Pulau Timor yang ada di bagian selatan.
\end{abstract}

Kata Kunci: Pulau Buru, Perang Dunia II, Arkeo-Historis

\begin{abstract}
In the context of the region, the presence of archaeological remains in the form of means of defense during World War II on the island of Buru can not be separated from the geographical context, where the Maluku Islands - including the Buru is part of the Pacific region. The problems studied in this paper is to reveal some form of defense and locations, as well as historical information related to World War II on the island of Buru. By using descriptive analysis and historical analogies, this study managed to identify forms of the means of defense which can still be observed in the form; facilities runway, pillbox and Australian troops landing site. Discussion of the results also uncovered the role of the island of Buru is a strategic region for the Japanese military and allied forces in World War II. The role of a strategic area is not separated from the geographical position of Buru Island that connects the Philippines in the north, Ambon in the east, and the island of Timor in the south.
\end{abstract}

Key Words: Buru Island, World War II, Historical-Archaeology

\section{PENDAHULUAN}

Secara geografis, Pulau Buru terletak di sebelah barat Pulau Seram dan berada pada arah barat laut Pulau Ambon. Selain kedua pulau tersebut, beberapa pulau kecil berada di sekitar Pulau Buru, yaitu; Ambalau di sebelah tenggara dan gugusan pulau Manipa, Kelang dan Buano yang membentang di sebelah timur hingga timur laut Pulau Buru. Kepulauan Sula juga merupakan gugusan pulau yang terletak di sebelah utara Pulau Buru. Saat ini, Pulau Buru terbagi atas dua wilayah pemerintahan administratif setingkat kabupaten yaitu Kabupaten Buru dan Kabupaten Buru Selatan yang merupakan bagian dari Provinsi Maluku.

Pulau Buru memiliki rentang historis yang panjang dimulai ketika masa kejayaan Kesultanan Ternate, dan kedatangan bangsa Eropa dalam upaya pencarian pusat rempahrempah. Rentang historis Pulau Buru berlanjut 
pada masa Perang Dunia II, dimana kekuatan militer Jepang menguasai seluruh wilayah nusantara hingga periode sejarah kontempore nusantara hingga periode sejarah kontemporer
Indonesia yang mencatat Pulau Buru sebagai Indonesia yang mencatat Pulau Buru sebagai
lokasi pembuangan tahanan politik pada awal era orde baru.

Historiografi Kepulauan Maluku menyebutkan bahwa wilayah Pulau Buru mendapat pengaruh dari Kesultanan Ternate. Pengaruh ini, tampak jelas dengan adanya perwakilan Sultan Ternate yang ditempatkan perwakilan Sultan Ternate yang ditempatkan
di Pulau Buru yang bergelar sangaji atau Gimelaha (Kimelaha). Selain Pulau Buru, wilayah-wilayah lain yang mendapat pengaruh adalah Pulau Seram (Hoamual), Kelang, Buano, dan Manipa (Leirissa, 1973: 86) Jangkauan pengaruh yang mencakup wilayahwilayah tersebut (Maluku bagian tengah), menunjukkan bahwa jaringan kekuasaan politik dan ekonomi Kesultanan Ternate menjangkau bagian selatan Kepulauan Maluku.

Sementara itu, catatan historis tentang Pulau Buru telah ada sejak awal abad ke-16, dimana bangsa Eropa mulai masuk ke wilayah Maluku. Catatan awal bangsa Eropa tercatat dalam Ekspedisi Francisco Serrão pada tahun 1512 dalam upaya pencarian pusat produksi cengkih. Catatan ini menyebutkan bahwa Pulau Buru merupakan salah satu persinggahan ekspedisi Serrão yang berangkat dari Gresik di Jawa dan melanjutkan perjalanan ke Ambon dan Seram sebelum menuju ke Banda (Andaya, 1993: 115). Catatan lain tentang Pulau Buru ditulis oleh Rumphius (1910), menyebutkan bahwa pada tahun 1648 sebuah ekspedisi VOC berhasil menangkap dan membakar kapal milik pedagang Makassa serta menghancurkan 3.000 pohon cengkih yang produktif di wilayah selatan Pulau Buru (Rumphius, 1910 II: 50; Grimes, 2006 : 144). Berbagai catatan awal ini menunjukkan bahwa sejak awal kehadiran bangsa Eropa Pulau Buru telah berperan penting dalam konteks perdagangan rempah-rempah masa lalu. Catatan Rumphius setidaknya memberi informasi bahwa Pulau Buru merupakan sala satu wilayah produksi cengkih di Maluku.
Dengan demikian, rentang historis Pulau Buru dapat dibagi dalam beberapa periode, yaitu: periode awal kedatangan bangsa Eropa, periode penguasaan Belanda (VOC dan Pemerintah Hindia Belanda), periode penguasaan militer Jepang, dan terakhir adalah periode Pulau Buru sebagai lokasi tahanan politik pada era orde baru. Dalam perspektif arkeo-historis, berbagai tinggalan arkeologi menandai periode rentang historis Pulau Buru. Periode kedatangan bangsa Eropa ditandai dengan keberadaan benteng Fort Defensie di Kayeli dimana saat itu, Kayeli merupakan pusat aktifitas dan pemerintahan Belanda di Pulau Buru. Buktipukti akeologis dalam periode pe bukti ankeologis dalam periode penguasaan Belanda juga terdapat di Kota Namlea sebaga pusat pemerintahan pada pergantian abad ke19 dan abad ke-20. Demikian halnya, periode penguasaan militer Jepang pada masa Perang Dunia II, ditandai dengan keberadaan sarana pertahanan di beberapa lokasi di Pulau Buru (Tim Penelitian, 2011). Sementara itu, pada periode Pulau Buru sebagai lokasi tahanan politik, rumah-rumah tahanan yang dulunya digunakan sebagai tempat tinggal masih dapat disaksikan hingga saat ini.

$$
\text { Dalam kerangka perspektif arkeo- }
$$

historis, informasi tentang keberadaan bukti-

bukti arkeologis periode Perang Dunia II belum banyak diketahui. Informasi-informas tentang bentuk-bentuk sarana pertahanan, termasuk lokasi keberadaannya, serta latar historis keberadaan sarana pertahanan tersebut. Pada akhirnya informasi buktibukti arkeologis tersebut dapat memberi pemahaman tentang peran Pulau Buru dalam kaitannya dengan periode Perang Dunia II.

Berdasarkan latar belakang permasalahan tersebut, tulisan ini difokuskan pada pembahasan periode Perang Dunia II di Pulau Buru, baik pada masa pendudukan pasukan sekutu maupun masa penguasaan militer Jepang. Fokus permasalahan yang dikaji dalam tulisan ini, diantaranya berkaitan dengan bentuk-bentuk sarana pertahanan, lokasi-lokasi atau toponim yang berkaitan dengan periode Perang Dunia II, serta latar historis periode Perang Dunia II di Pulau Buru. Dalam konteks pembahasan ini, maka penulisan ini dimaksudkan untuk mengisi ruang informasi historiografi Pulau Buru berkaitan dengan Periode Perang Dunia II. Adapun metode penulisan yang digunakan adalah metode studi pustaka, dimana data utama penulisan ini bersumber dari hasil penelitian yang dilakukan oleh Balai Arkeologi Ambon di Pulau Buru pada tahun 2011 (Tim Penelitian, 2011). Metode analisis deskriptif juga digunakan untuk memberikan gambaran tentang berbagai bentuk tinggalan arkeologi yang ada di lokasi penelitian. Selanjutnya, untuk menambah informasi tentang latar historis, maka dilakukan penelusuran lanjutan baik melalui buku maupun melalui sumber-sumber lain dari media online yang berkaitan dengan periode Perang Dunia II di Pulau Buru.

\section{HASIL DAN PEMBAHASAN \\ a. Profil Wilayah}

Secara administratif, lokasi penelitian berada pada dua wilayah Kecamatan yaitu Kecamatan Waeapo dan Kecamatan Namlea, kedua wilayah kecamatan ini merupakan wilayah adminstratif Kabupaten Buru, Provinsi Maluku. Kota Namlea dapat dijangkau dengan menggunakan transportasi laut dan udara. Transportasi laut dapat dijangkau dengan dua alternatif yaitu menggunakan armada Feri dan Kapal Cepat. Moda transportasi Feri berangkat dari dermaga fery yang ada di Baguala dengan waktu tempuh 8 jam, sedang Kapal Cepat berangkat dari Pelabuhan Kecil (Belakang Kota) dengan waktu tempuh \pm 4 jam. Jenis transportasi udara yaitu dengan pesawat perintis yang berangkat dari bandara Pattimura di Kota Ambon menuju bandara milik TNI-AU yang ada di Kota Namlea dengan waktu tempuh \pm 30 menit.

Jumlah penduduk Kabupaten Buru berdasarkan sensustahun 2011 adalah Penduduk 111.447 jiwa dengan laju pertumbuhan penduduk sekitar 3,93\%. Kabupaten Buru terbagi atas lima wilayah kecamatan yaitu Kecamatan Namlea, Kecamatan Waeapo, Kecamatan Waplau, Kecamatan Batabual, dan Kecamatan Air Buaya. Kabupaten Buru mengalami pemekaran wilayah pada tahu 2008 berdasarkan Undang-Undang Nomor 32 Tahun 2008 tentang terbentuknya Kabupaten Buru Selatan. Secara fisik, Kabupaten Buru dibatasi oleh:

- Sebelah Barat

:Laut Banda

- Sebelah Timur : Selat Manipa

- Sebelah Utara : : Laut Seram

- Sebelah Selatan : Kabupaten Buru Selatan. Secara kesuluruhan, luas Pulau Buru adalah 7.594, $98 \mathrm{Km}^{2}$ dengan panjang 140 $\mathrm{km}$ dan lebar $90 \mathrm{~km}$, serta garis pantai 232,18 $\mathrm{Km}$. Puncak bukit/gunung yang ada di pulau ini adalah Kan Palatmada dengan ketinggian 2.429 mdpl. Terdapat 3 (tiga) blok pegunungan yang masing-masing dipisahkan oleh struktur kelurusan lembah. Pada bagian barat tapak Kan Palatmada dengan ketinggian diatas 2000 mdpl, dimana dibatasi oleh lembah depresi Sungai Nibe-Danau Rana dan Sungai Wala Pada blok tengah dengan ketinggian di atas 1000 mdpl yang dibentuk oleh Teluk Kayel dan Lembah Apu, sedangkan blok selatan dibentuk oleh Lembah Kalua dengan Gunung Batabual $1.731 \mathrm{mdpl}$. Secara astronomis, Kabupaten Buru terletak antara $2^{\circ} 25^{\prime}-3^{\circ} 55^{\prime}$ Lintang Selatan dan $125^{\circ} 70^{\prime}-127^{\circ} 21^{\prime}$ Bujur Timur.

b. Sarana Pertahanan Masa Perang Dunia II di Pulau Buru

1. Lokasi Pendaratan Tentara Australia Lokasi ini berada di daerah pesisir pantai di Kampung Jiku Merasa, dan secara astronomis berada pada S $03^{\circ} 13.953^{\prime}$ da E $127^{\circ} 06.610^{\prime}$. Di lokasi ini terdapat dua struktur berbentuk bulat dari bahan beton dengan campuran batu karang. Ukuran masing-masing struktur; adalah Struktur I, dengan diamtere $415 \mathrm{~cm}$, kedalaman 220 $\mathrm{cm}$, tinggi $90 \mathrm{~cm}$ dari permukaan tanah (pengukuran pada bagian luar). Pada bagian 
atas terdapat penutup yang juga terbuat dari semen dengan rangka besi, pada bagian inipula terdapat lubang dengan ukuran $60 \mathrm{x}$ $60 \mathrm{~cm}$, dengan ketebalan $15 \mathrm{~cm}$. Sementara itu, Struktur II, dengan kedalaman $210 \mathrm{~cm}$, tebal $31 \mathrm{~cm}$, tinggi $71 \mathrm{~cm}$ dari permukaan tanah (pengukuran pada bagian luar). Jarak antara kedua struktur ini adalah $15,7 \mathrm{~m}$.

Tidak diketahui fungsi kedua struktur yang ada di lokasi, namun informasi penduduk menyebutkan bahwa lokasi ini merupakan lokasi pendaratan tentara Australia yang merupakan bagian dari pasukan sekutu menghadapi militer Jepang dalam Perang Dunia II. Indikasi lain yang ada di lokasi in adalah struktur yang saat ini telah berada $\mathrm{di}$ tepi laut yang diduga merupakan bagian dar sebuah dermaga

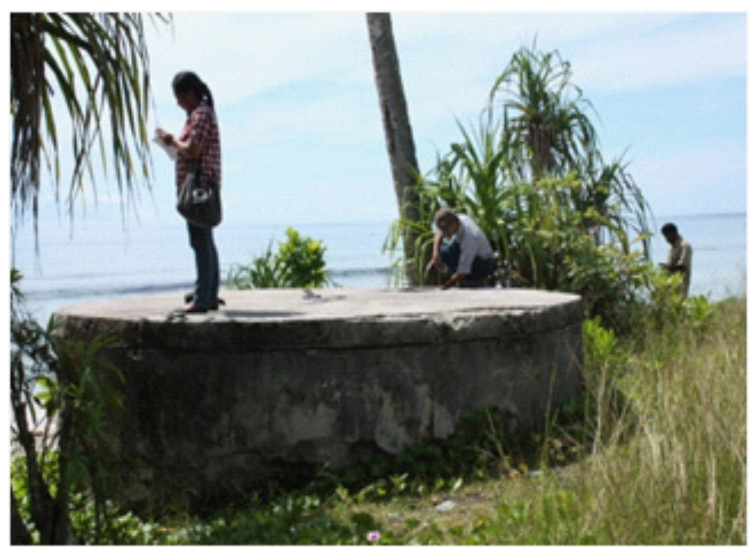

Foto 1: Struktur I yang terdapat di lokasi pendaratan Tentara Australia Sumber: Dokumentasi Bala Arkeologi Ambon, 2011

\section{Lapangan Terbang}

Secara astronomis, lokasi ini berada pada titik S $03^{\circ} 14.284^{\prime}$ dan E $127^{\circ} 06.142^{\prime}$. Lapangan Terbang ini memiliki landasan pacu sepanjang 750 meter dengan lebar 23 meter. Lokasi lapangan terbang berjarak sekitar 6 kilometer arah barat daya kota Namlea. Saat ini, lapangan terbang yang merupakan peninggalan Perang Dunia I dikuasai oleh TNI-AU, bandara ini juga difungsikan sebagai bandara komersial yang melayani penerbangan perintis yang menghubungkan Namlea dengan Ibukota Propinsi.

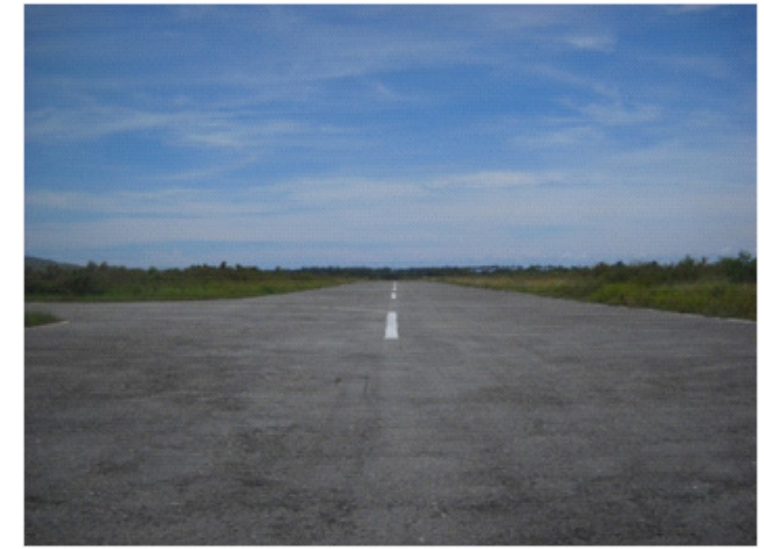

Foto 2: Landasan pacu bandara Namlea yang merupakan peninggalan Perang Dunia II (saa ini masih difungsikan oleh TNI-AU). Sumber

Dokumentasi Balai Arkeologi Ambon, 2011.

Selain lapangan terbang, temuan lain yang ada di lokasi ini adalah dua pillbox dengan bentuk dan ukuran yang berbeda, yaitu:

Pillbox I, terdiri atas dua bagian, yaitu bagian atas dengan ukuran lebih kecil berbentuk segi delapan dengan ukuran tiap sisi adalah $80 \mathrm{~cm}$, dan ketebalan dinding 33 $\mathrm{cm}$. Pada bagian bawah berbentuk lingkaran dengan diameter $5,20 \mathrm{~m}$. Pada tiap bagian terdapat lubang intip, pada bagian atas (bentuk segi delapan) terdapat delapan lubang intip yang ada pada tiap sisi dengan ukuran 25 x $35 \mathrm{~cm}$. Sementara itu, pada bagian bawah (bentuk lingkaran) terdapat 13 lubang intip dengan ukuran $10 \times 10 \mathrm{~cm}$. Kedua bagian ini dihubungkan oleh sebuah lubang dengan ukuran $50 \times 51 \mathrm{~cm}$, demikian pula pada bagian atas terdapat lubang dengan ukuran yang sama. Pada bagian bawah bunker in terdapat sebuah pintu masuk dengan ukuran $60 \times 80 \mathrm{~cm}$.

Pillbox II, bunker ini memiliki lima lubang intip dengan ukuran $20 \times 20 \mathrm{~cm}$, dan sebuah pintu dengan ukuran $82 \times 72 \mathrm{~cm}$. Sementara itu, ketebalan bunker adalah 33 $\mathrm{cm}$. Jarak antara kedua bunker adalah 36 , $60 \mathrm{~m}$.

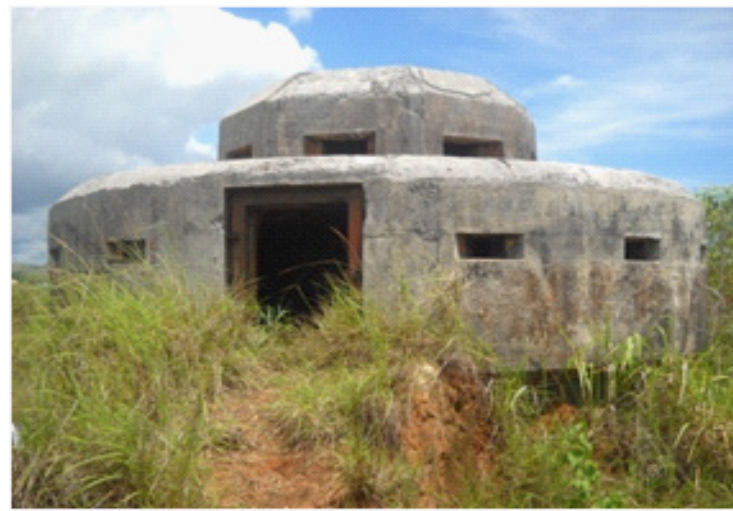

Foto 3: Pillbox I yang terdapat di sekitar Lapangan Terbang milik TNI-AU. Sumber: Dokumentasi Balai Arkeologi Ambon

c. Periode Perang Dunia II di Pulau Buru Dalam berbagai sumber disebutkan bahwa gelombang serangan pasukan Jepang terhadap wilayah Hindia Belanda, selain dimaksudkan untuk menguasai sumbersumber minyak, sekaligus merupakan upaya militer Jepang untuk melumpuhkan kekuatan Hindia Belanda yang saat itu berpusat di Jawa. Aspek strategis lain, bahwa secara geografis (khususnya wilayah timur) penguasaan atas (khususnya wilayah timur) penguasaan atas
wilayah ini dimaksudkan untuk mendekatkan wilayah ini dimaksudkan untuk mendekatkan yang saat itu merupakan salah satu bagian dari kekuatan Sekutu. Gelombang serangan yang berpusat di Davao Philipina, dimulai pada tanggal 11 Januari 1942 dan berturut-turut menguasai beberapa wilayah di Indonesia hingga 20 Februari 1942. Sementara itu, serangan militer Jepang ke wilayah Maluku khususnya Ambon berlangsung sejak tanggal 30 Januari 1942. (Ojong, 2006: 7; Syahruddin, 2011: 53).

Periode penguasaan militer Jepang dan pasukan sekutu di Pulau Buru berlangsung pada masa Perang Dunia II yaitu tahun 1942 hingga 1945. Sebelum serangan militer Jepang pada awal tahun 1942, pihak sekutu yang tergabung dalam Aliansi negera-negara sekutu telah mempersiapkan kekuatan militer mereka. Dalam hal ini, Pemerintah Australia (salah satu negara aliansi) sepakat untuk mengirimkan bantuan militer ke beberapa lokasi penting di wilayah Hindia Belanda.
Dalam kerjasama tersebut, Pemerintah Hindia Belanda bekerjasama dengan Pemerintah Australia sepakat untuk membentuk sistem pertahanan yang disebut "The Defence Of The Ambon-Timor-Darwin Triangle" untuk menghadapi kemungkinan serangan pasukan Jepang ke wilayah Hindia Belanda (Indonesia) Dan, tanggal 7 Desember 1941, Pemerintah Australia mengirimkan bantuan militer ke Ambon termasuk Namlea (Pulau Buru) dan Pulau Seram (Bussemaker, 1996; Syahruddin, 2011: 53). Kontak antara pasukan Jepang dan pasukan Sekutu (ABDA/AmericanBritish-Dutch-Australia) berlangsung sejak 25 Januari hingga akhirnya pasukan Jepang menguasai bandar udara yang ada di Pulau Buru pada12 Februari 1942 (Broodmetkaas, 2012)

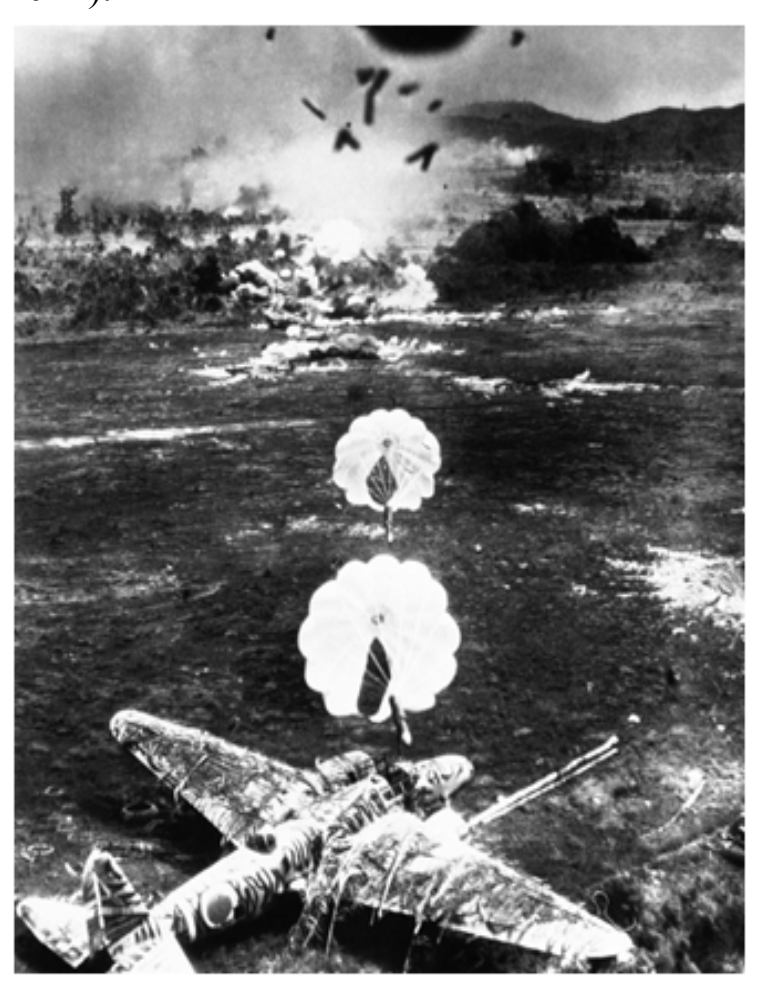

Foto 4. Serangan tanggal 15 Oktober 1944 terhadap Fasilitas Landasan Pacu Kekuatan Militer Jepang di Namlea, Pulau Buru.

(Sumber: www.theatlantic.com)

Setelah kekalahan Belanda dan Australia di wilayah Hindia bagian timur, Amerika dengan peralatan perang yang lebih lengkap dan modern kemudian memegang 
peran penting dalam upaya menghalau militer Jepang. Periode akhir Perang Dunia II di Pulau Buru terjadi pada saat serangan balik yang dilakukan oleh pasukan Sekutu di bawah komando Jenderal Mc Arthur Tujuan dari serangan balik yang dilakukan oleh Amerika adalah menguasai kembal pangkalan militer mereka yang direbut oleh Jepang di Philipina. Dengan tujuan utama tersebut, pasukan sekutu sebelumnya berusaha melumpuhkan kekuatan Jepang yang tersebar di beberapa wilayah di Hindia Timur termasuk yang ada di Namlea. Untuk itu, Pasukan Sekutu yang terdiri atas kekuatan udara 5th Air Force dan Far Eas Air Force (FEAF) melakukan seranganserangan sporadis terhadap kedudukan pasukan Jepang di Namlea yang berlangsung selama bulan Mei 1943 hingga Januari 1945 yang melibatkan pesawat pembom B-24, B-25, A-20 dan P-38 (Pacific Wrecks, 2011) Akhirnya, pada tahun 1945, militer Jepang menyatakan kalah perang dan menyerahkan kekuasaannya kepada Pasukan Sekutu.

Jika mengamati keberadaan bukti bukti arkeologis periode Perang Dunia I berada di sisi utara Pulau Buru, sehingg tampak jelas keletakan geografis lokasi-lokas tersebut berorientasi ke arah utara. Analisa pertama bahwa sarana pertahanan telah dibangun oleh gabungan militer Pemerintah Hindia Belanda dan Pemerintah Australia. Sarana pertahanan berupa bandar udar yang dilengkapi dengan beberapa pilbox sekitarnya, serta lokasi pendaratan tentara Australia yang tidak jauh dari lokasi bandara yang masing-masing berada di sisi utara Pulau Buru. Pembangunan sarana pertahanan in dimaksudkan untuk menghadapi serangan militer Jepang yang kemungkinan datan dari arah utara. Hal ini mengingat awa serangan militer Jepang ke wilayah Hindi Belanda berpusat di Davao Philipina. Pada awal periode Perang Dunia II, militer Jepang didukung oleh kekuatan persenjataan saa itu, sehingga wilayah Hindia Belanda dapa dikuasai dengan cepat termasuk Pulau Buru. Selain itu, strategi Militer Jepang dalam melakukan serangan ke wilayah Hindia Belanda lebih mengut penting. Dalam konteks kawasan Ambon dan sekitarnya, serangan militer Jepang dipusatkan di Kota Ambon dan setelah mereka berhasi menguasai titik lokasi penting tersebu barulah kemudian diarahkan ke wilayahwilayah sekitarnya yang merupakan "wilayah sayap". Dalam hal ini Namlea yang ada di Pulau Buru merupakan "wilayah sayap" kekuatan gabungan militer Hindia Belanda dan Australia.

Pada periode berikutnya, setelah militer Jepang berhasil menguasai Pulau Buru, lokasi sarana pertahanan tersebut dimanfaatkan untuk menghadapi serangan balik dari Pasukan Sekutu. Berdasarkan pengamatan di lokasi sarana pertahanan yang ada berupa landasan pacu dan sebaran titik lokasi Pillbox, menunjukkan bahwa militer Jepang tidak membangun sarana pertahanan yang cukup memadai untuk menghadapi serangan balik dari sekutu Selain itu, kekuatan militer Jepang dalam hal jumlah telah jauh berkurang dibanding ketika mereka memulai invasi ke wilayah AsiaPasifik. Taktik atau serangan harakiri militer Jepang (pesawat bom bunuh diri, biasanya bertujuan untuk menghancurkan target dengan menabrakkan pesawat yang memuat bahan peledak), tampaknya merupakan bumerang yang justru melemahkan kekuatan mereka dari aspek kuantitas pesawat tempur. Faktor lain, pada periode akhir Perang Dunia II, teknologi persenjataan militer Jepang jauh ketinggalan dibanding teknologi persenjataan yang dimiliki oleh Pasukan Sekutu. Hal in tampak pada berbagai serangan sporadis yang dilancarkan oleh Pasukan Sekutu yang memiliki kekuatan pesawat tempur dengan akurasi yang tinggi. Seranganserangan sporadis ini mulai dilancarkan sejak pertengahan tahun 1943 hingga awal tahun 1945. Menjelang akhir tahun 1945, Jepang kemudian menyatakan kalah dan menyerahkan kekuasaannya kepada pasukan Sekutu.

\section{PENUTUP}

Berdasarkan hasil survey di lapangan diperoleh informasi tentang keberadaan sarana pertahanan pada masa Perang Dunia II di Pulau Buru. Sarana pertahanan berupa fasilitas landasan pacu, titik lokasi sebaran pillbox, dan lokasi pendaratan pasukan Australia. Sarana-sarana pertahanan ini berada di lokasi yang saling berdekatan dan berada di sisi utara Pulau Buru. Asumsi bahwa sarana pertahanan ini dibangun oleh Pemerintah Hindia Belanda bekerjasama dengan Pemerintah Australia menunjukkan bahwa secara geografis, lokasi ini adalah lokasi ideal untuk menghadapai serangan militer Jepang. Sebagaimana diketahui militer Jepang saat itu, memulai serangan ke wilayah Hindia Belanda melalui Philipina yang ada di bagian utara Kepulauan Maluku.

Konteks peran wilayah Pulau Buru dalam kancah Perang Dunia II tidal lepas dari konteks kawasan Kepulauan Maluku yang menjadi bagian dari kawasan pasifik. Keterlibatan Amerika Serikat, Australia, dan Hindia Belanda dalam perang ini menjadikan kawasan pasifik sebagai salah satu "arena" dalam Perang Dunia II yang disebut "Theater of Pacifik". Dengan demikian, militer Jepang berkepentingan untuk menguasai seluruh wilayah Hindia Belanda. Selain kepentingan militer kawasan, Jepang juga memiliki kepentingan ekonomi, karena adanya embargo minyak terhadap negara tersebut, sebagaimana diketahui bahwa wilayah Hindia Belanda yaitu Pulau Kalimantan dan Pulau Timor merupakan sumber minyak pada saat itu. Berbagai kepentingan inilah yang kemudian menjadi faktor utama kehadiran militer Jepang di kawasan Hindia Belanda termasuk di Kepulauan Maluku.

Meski kuantitas tinggalan arkeologi yang berkaitan dengan masa Perang Dunia II di Pulau Buru tidak banyak dengan sebaran yang kurang, namun tinggalan arkeologi ini penting dilestarikan sebagai penanda kehadiran pasukan sekutu maupun militer Jepang dalam konteks Perang Dunia II. Pentingnya melestarikan setiap sumberdaya arkeologi yang ada dimaksudkan sebagai Distoris suatu wilayah termasuk Pulau Buru. Demikian, tulisan ini diharapkan dapat melengkapi informasi rentang historis Pulau Buru dan dapat mengungkap nilai penting sunberdaya arkeologi yang ada di Pulau Buru. 


\section{DAFTAR PUSTAKA}

Andaya, L.Y. 1993. The World of Maluku: Eastern Indonesia in the Early Modern Period. Honolulu: University of Hawaii Press.

Broodmetkass, 2007. Chronological Summary of Events in the Former Dutch East Indies From Descember-3-1941 to December-31-1941.Diunduh Tanggal 13 Januari 2012 dari: http://broodmetkaas. com/blog/2007/03/21/chronologicalsummary-of-events-in-the-former-dutcheast-indies-from-december-3-1941-todecember-31-1941/

Bussemaker., H. 1996. Australian-Dutch Defence Cooperation 1940-1941. dalam Australian War Memorial. University of Amsterdam. The Netherlands. Diunduh tanggal 18 Februari 2011, dari: http://awm.gov. aujournalj29herman.asp/herman.asp.htm

Grimes, B.D. 2006. Mapping Buru: The Politics of Territory and Settlement on an Eastern Indonesian Island (page 135-155). Dalam Sharing the Earth, Dividing the Land: Land and Territory in The Austronesian World. Thomas Reuter and Thomas Anton Reuter (edited). Canberra: ANU-Press.

Leirissa, R.Z. 1973. Kebijaksanaan VOC untuk Mendapatkan Monopoli Perdagangan Cengkeh di Maluku Tengah antara Tahun 1615 dan 1652. Dalam Bunga Rampai Sejarah Maluku (I). Jakarta: Lembaga Penelitian Sejarah Maluku.

Ojong., P.K., 2006. Perang Pasifik, Cetakan IX 2006. Jakarta: Penerbit Buku Kompas

Rumphius, G.E. 1910. De Ambonsche historie, behelsende een kort verhaal der gedenkwaardigste geschiedenissen zo in vreede als oorlog voorgevallen sedert dat de Nederlandsche Oost Indische Comp. het besit in Amboina gehadt heeft. 2 parts. Bijdragen tot de Taal-, Land- en Volkenkunde, 64.
Syahruddin, Mansyur., 2011. Tinggalan Perang Dunia II di Ambon: Tinjauan Atas Sarana Pertahanan dan Konteks Sejarahnya. Dalam Jurnal Kapata Arkeologi ISSN 1858-4101, Hal. 43-61. Ambon. Balai Arkeologi Ambon.

Tim Penelitian. 2011. Laporan Penelitian Arkeologi: Pengaruh Kolonial di Wilayah Pulau Buru Kabupaten Buru Propinsi Maluku. Ambon: Balai Arkeologi Ambon.

Pacific Wreck, 2011. "American Missions Against Halong and Halong Seaplane Base". Diunduh tanggal 18 Februari 2011, dari http://www.pacificwrecks.com/airfields/ indonesia/halong/missions-halong.html

Sumber Peta dan Gambar:

Peta Pulau Buru. Link:

http://ms.wikipedia.org/wiki/Fail:Topographic_ map_of_Buru-en.svg

Foto 4. Serangan Pasukan Sekutu ke Pulau Buru. Link: http://www.theatlantic.com/ infocus $/ 2011 / 09 /$ world-war-ii-the-pacificislands/100155/\#img27 